of twenty years earlier gives a clear idea of the author's view that there will, in the next five years or so, be a considerable increase of shipbuilding, and, therefore, of prices above the present low levels. He points to the advantage, where immediate profits can be dispensed with, to be derived from building when prices are low and obtaining a few years later enhanced rates together with capital appreciation.

On the technical side it is shown that for efficiency, design and specification must be suitable for the particular trade for which the vessel is intended, that features which are nothing more than fads must be eliminated, and that accommodation for officers and crew should be such as to attract the best type of men. Drawings of the S.S. Dumfries are appended to show the author's idea of a good plain cargo vessel with a well-balanced specification and arranged on simple and efficient lines. Questions of strength and weight should be left to the classification societies as the greatest authorities on the subject and the depositories of data relating to structural trouble experienced with ships in service. Stream-lining of the rudder and stern frame is recommended as one of the conditions essential to efficiency.

On the subject of service speed, the author indicates the retarding effects on a vessel in a sea-way due to rolling, pitching, heaving and yawing, and the additional fluctuations due to orbital velocity of the surface of the water which in waves $6 \frac{1}{2} \mathrm{ft}$. high and $100 \mathrm{ft}$. in length has been found to be as much as $2 \frac{3}{4}$ knots. To maintain the service speed against such adverse conditions, he considers it advisable to give the vessel a form suitable for a speed $\frac{1}{2}-3$ knots (according to trade) in excess of the service speed demanded, and suggests that on trial the engines should be able to develop 15 per cent surplus power on the Skelmorlie mile (or 10 per cent on Hartley). As a standard of propulsive efficiency, Ayre's basis is taken and data are adduced regarding four types of vessel, including one of the $B$ Standard vessels, and their performances are analysed and compared in detail on this basis.

\title{
Embryology of Angiosperms
}

\begin{abstract}
$\mathrm{A}^{\mathrm{N}}$ $\mathrm{N}$ article by Dr. P. Maheshwari from Current Science of June last, entitled "Progress of Work in India on the Embryology of Angiosperms", reviews the considerable amount of research already completed in his own department at the Agra College and at other Indian botanical centres.

Contributions from Agra include a series of papers by B. M. Johri on the embryology of the Alismataceæ as illustrated by species of Limnophyton and Sagittaria, with a review of previous work on the family : there is some variability in development in the embryo-sac and in endosperm formation. B. L. Gupta gives a comparative account of previous work on the embryology of the Potamogetonaceæ and contributes results of his own researches on pollen and ovuledevelopment in Potamogeton crispus and Wolffia arrhiza. Wolffia shows several important differences in this respect from the allied genus Lemna. Similar work on the Centrospermales is found in studies by H. R. Bhargava on Boerhaavia (Nyctaginaceæ) and Mollugo and Trianthema (Aizoaceæ) and by V. Puri and B. Singh on Digera (Amarantaceæ). In a comparative review of embryological work on the
\end{abstract}

Centrospermales, Puri and Singh suggest the separation of the Portulacaceæ, Basellaceæ and Caryophyllaceæ as a distinct order. Species of Neptunia (Mimosaceæ), Eclipta (Compositæ) and Cuscuta have also been studied. In a paper on the gametophytes of Berberis nepalensis, Johri discusses the relationship between the families Ranunculaceæ and Berberidaceæ. The marked similarity in members of the two families in sporogenesis and gametogenesis suggests their close alliance in spite of differences in floral structure which have been used to separate them in distinct orders.

Dr. Maheshwari introduces a study of the life-history and anatomy of Ephedra foliata with an account of the development of the two gametophytes. With B. Singh he contributes an account of the morphology and anatomy of the fern, Ophioglossum fibrosum. In his general article referred to above, he stresses the importance of a study of the plants in their entirety in approaching a natural system of classification. He also refers to the serious difficulty arising from paucity of literature in India, and pleads for a more general exchange of reprints and journals.

\section{Experiments in Salmon Marking in Norway, I935} \begin{abstract}
A NOTABLE paper has just been published by subject (Statens Forsøksvirksomhet for Ferskvanns. fiskeri, Oslo. I. Matem.-Naturwid. Klasse, 1935. No. 12), and it is demonstrated that Salmo salar has a wider range in its migratory movements than was supposed, or at any rate than had been proved in Europe.

The Scottish coastal marking carried on for a number of years in the Moray Firth and east and north coasts of Sutherland certainly resulted in a
\end{abstract}

large number of recaptures and records published by the Fishery Board for Scotland---up to 38 per cent of the fish marked in one of the seasons-and shed a good deal of light on the movements of fish round the coast. Indications were collected also from the capture of salmon, at infrequent intervals, at far distant points, that the Atlantic salmon ranged widely. But the Norwegian results now published prove this to be the case.

The authors are of opinion that the high percentage of recaptures-reaching 48 per cent-is due really 
to the fact that the marks used had the place of origin indicated upon them ("Zool. Museum, Oslo") as well as a distinguishing number, and that on this account the reporting of recaptures was more complete. In the Scottish operations we relied upon a wide circulation of the occurrence of the marking and the offer of rewards, but on one or two occasions it did happen that the report of a recapture was obtained only after the fish had made a railway journey to market. Also, the Norwegian marks were inserted not in the base of the dorsal fin, but were wired through the back just in front of the dorsal fin, where the mark was more conspicuous.

The greatest distance recorded from the Scottish marking was about 620 miles, being the shortest distance from the Spey round the north of Scotland to the Eden in Cumberland. On the Pacific coast of North America 'tagging' had shown greater distances than this, and operations at the Alaskan Peninsula had yielded not only long distances but also some interesting information about the pace of travel at different times of the year. Newspaper reports had even told of a salmon (Onchorynchus) from this set of operations that followed the line of the Aleutian Islands and had been captured in Kamchatka by Japanese fishermen. This journey is well over 1,000 miles. From the west of Vancouver Island also fish had gone south to the Columbia River, a distance of 800 miles.

The Norwegian records now give one example of a fish having travelled from Titran on an island off the Trondhjem Fiord, north to the Wyg River in the Gulf of Onega in the White Sea, a distance of 2,500 kilometres, which is approximately 1,500 miles. Lesser distances are $1,100 \mathrm{~km} ., 800 \mathrm{~km}$. and $700 \mathrm{~km}$. It is interesting to notice also that one fish, marked at Rong not far from Bergen, had gone south-west across the North Sea to Montrose, the interval of time being 19 days and the distance $550 \mathrm{~km}$., which is approximately 350 miles.

This paper opens up a new vista of the range of $S$. salar, and some interesting particulars are given also about smolt marking carried out by Dr. Gunnar Alm in the Baltic, and showing wide movements.

W. L. Calderwood.

\section{Educational Topics and Events}

London.-Mr. D. G. Catcheside, lecturer in botany in King's College, has been awarded a Rockefeller fellowship in cytological genetics. $\mathrm{He}$ is to spend a year in Dr. T. H. Morgan's laboratory at the California Institute of Technology, Pasadena, be. ginning in September 1936.

Sr. Andrews.--The Senatus Academicus has resolved to confer the honorary degree of LL.D. on the following, among others, at the graduation ceremonial to be held in June.: Mr. David Anderson, of the firm of Messrs. Mott, Hay and Anderson, consulting engineers, London; Prof. J. E. Littlewood, Rouse Ball professor of mathematics in the University of Cambridge; Major F. J. J. Ney, executive secretary, National Council of Education of Canada, Toronto, Canada; Prof. E. W. Reid, emeritus professor of physiology, University College, Dundee.
ShefFIELD.-Lord Crewe, Chancellor of the University, will open the new University Students' Union building on Saturday, May 2. The building was made possible through the generosity of Alderman J. G. Graves, who gave $£ 15,000$, the cost of the building. Before opening the building, Lord Crewe will confer honorary degrees upon the following, among others : Sir Charles Grant Robertson, Vice Chancellor of the University of Birmingham; Sir Harold Hartley, vice-president and director of scien. tific research of the L.M.S. Railway Company; Sir Frank Smith, secretary of the Department of Scientific and Industrial Research and secretary of the Royal Society ; Sir Harold Carpenter, professor of metallurgy in the Royal School of Mines.

The American National Research Council has administered during the past sixteen years a postdoctoral fellowship scheme, financed by the Rockefeller Foundation, involving the expenditure of nearly four million dollars. It seems that the Foundation, while continuing to take a keen interest in the postdoctoral fellowship principle, will not continue its support on the same scale and in the same way as in the past; and some anxiety has, in consequence, been aroused in university circles as to ways and means for ensuring the maximum of opportunity for minds capable of productive scholarship. At the thirty. seventh annual conference of the Association of American Universities held at Cornell University last November, this question was discussed in papers by Prof. F. R. Lillie of the National Research Council, Dr. K. T. Compton, president of the Massachusetts Institute of Technology and Dr. Ray Lyman Wilbur, president of Stanford University. The National Research fellowships are comparable in aim and scope with the fellowships instituted in Great Britain in 1891 by the:Royal Commission for the Exhibition of 1851 and, like them, have this great advantage over fellowships awarded by universities, that the field of selection is enormously wider. Dr. Compton's paper outlined an ingenious plan, the essential features of which are : the offer by each of a group of associated universities of fellowships for research to be carried out within it, and the assumption of the task of selecting fellows by an independent board which receives applications from candidates throughout the country. A schedule of stipends uniform for all the universities would tend to prevent candidates' choice from being influenced by financial considera. tions. Such a scheme would, Dr. Compton believes, if subscribed to by a sufficient number of universities, be subsidised by the Rockefeller and other founda. tions.

Harvard University celebrates this year the three-hundredth anniversary of its foundation. The occasion is to be marked by inaugurating two schemes of high importance, the outcome of what is termed "a new appraisal of the University's place and function in the life of the nation". One of them is for the creation of 'university professorships' of a novel kind, affording to teachers and scholars of unusual scope and ability broader opportunities than have hitherto been available in American universities. The Harvard authorities are impressed by the realisation that all subjects which are intensively studied lead into other subjects, and the occupants of the new chairs, while not exactly "professors of things-in. general", will be limited by the scope of their own 